\title{
Identifying the Factors that Attract Ciputra and Petra Christian University Students as a New Target Market to Come to Xiang Fu Hai of Vasa Hotel Surabaya on Weekdays
}

\author{
Magdalena Patricia \\ English Department, Faculty of Languages Ana Literature, Petra Christian University, Siwalankerto 121- \\ 131, Surabaya 60236, INDONESIA \\ E-mail: m11415046@john.petra.ac.id
}

\begin{abstract}
Xiang Fu Hai is a Chinese restaurant of Vasa Hotel Surabaya which has started its business from 2017. Even though Xiang Fu Hai has already established for 2 years, Xiang Fu Hai has a low number of customers on weekdays. However, on weekends, this Chinese restaurant is always full of customers. Xiang Fu Hai cannot depend on the existing customers and has to find a new target market which is university students. A marketing research for a new target market is needed to know the factors that can attract them to come to Xiang Fu Hai. The marketing research help Xiang Fu Hai to create offers which match with the university students needs and demand, and the offers can run effectively and successfully. By having a marketing research, the company has the base to make right offers, so they will not waste much time and money for trials and errors.
\end{abstract}

Keywords: customer, new target market, university students, marketing research, offers.

\section{INTRODUCTION}

As we can see, in Surabaya, there are lots of Chinese restaurants in Surabaya, from the lowmiddle class until high class restaurants. One of the Chinese restaurants in Surabaya is Xiang Fu Hai located in Vasa Hotel Surabaya, West Surabaya. Xiang Fu Hai was started its business as a 5-star-hotel Chinese restaurant from 2017. However, I saw there was a problem in the number of Xiang Fu Hai's customer. Even though Xiang Fu Hai has already established for 2 years, Xiang Fu Hai has a low number of customers on weekdays. However, on weekends, Saturday and Sunday, this Chinese restaurant is always full of customers. The most of customers who come to Xiang Fu Hai on weekends are rich families. The heads of families or fathers are the one who will pay the bills. After interviewing some employees and observing the problem, I can see the factor that makes a number of customers low in weekdays.

Waitress of Xiang Fu Hai asked a customer who came on the weekend, why she did not have lunch on weekdays with her family. The customer answered that her family was complete only on Sunday. If they went to Xiang Fu Hai on weekdays, most of them had their own agenda. Based on the short interview, I can conclude that the first possible cause is because of the time. For old people, they put a value on time, especially for rich people. That is why there is a proverb, time is money. By spending little time, bosses can make lots of money. If Xiang Fu Hai wants to move this kind of customers to the weekdays, they will not want to change the day. Even though there is a promotion in weekdays, they will still choose weekends for eating out. The price or promotion will not affect the day they come to Xiang Fu Hai. For, only on weekends, they can eat out with their full-team members of families.

Xiang Fu Hai also has a huge space or big capacity. However, in the weekdays, it is usually only filled by 50 people from afternoon until evening. The capacity and the resources that Xiang Fu Hai has did not use as well as it can be used. If Xiang Fu Hai is compared by other Chinese 
restaurants, Xiang Fu Hai has low performance. Ming Garden, which is placed right across, is always crowded by customers. In the morning, at least 9 tables for 10 people is always full of customers. The customers who come to Ming Garden, are more less the same with Xiang Fu Hai's target market. In the afternoon, there are lots of cars park inside the parking area which means a lot of customers come to Ming Garden for lunch. Another competitor is Moi Village which is located in Mayjend Yono Street. Moi Village opens at 11.00 until 14.15. Then, they have a break and starts again from 18.00 until 21.15. The working hour is almost same with Xiang Fu Hai's working hour, but the performance is better Moi Village than Xiang Fu Hai. In the afternoon, $75 \%$ of Moi Village seats are full in weekdays. It can be seen from the Google review too. The performance on weekdays is high and stable.

Seeing Xiang Fu Hai's condition, Xiang Fu Hai needs a new target market on weekdays which is university students. The reason why I choose university students as Xiang Fu Hai new potential market is that the university students have already had enough money for eating out in the five-star hotel. I have done small research among university students. $65.9 \%$ of university students have income of more than 1 million rupiahs. The income here is the net income (not include the boarding house/living, transportation, and course/university cost) that they earn. Then, university students also can be long-term customers of Xiang Fu Hai. If it is compared with the adult customer, university students live 20 years longer than $40-50$ years people. In $2020,34 \%$ of Indonesia population also will be dominated by milennials who are university students now (Alexander, 2018). Last, university students also have buying power. Young people are people who like to try something new. For example, Huang Ji Huang's (the new Chinese restaurant in HR. Muhhamad) customers are dominated by young people or university students. This habit can be an opportunity for Xiang Fu Hai to make more customers come to Xiang Fu Hai on weekdays. Also, 71.4\% of young people spend their income for eating out (Debora, 2017). By making a research based on what the university students' needs and demands, it will be a good start for Xiang Fu Hai to make an effective offer. The questions of the questionnaire also depend on the Xiang Fu Hai condition or resources. This research will be useful for a long-term plan. After having the respondents' answer or data, I will observe the data and make a report of it. Based on the research, I will also give an example in the form of a digital flyer, to know how the research can be used.

\section{METHODS}

The tool which I will use to solve Xiang Fu Hai's problem is marketing research. The research consists of 25 selected questions based on the problem that wants to be solved in Xiang Fu Hai. There are 2 sections in the questionnaire, the preliminary questions, and developed questions. The preliminary section asks about the identity of the respondents and the developed section asks about Xiang Fu Hai. In the developed questions, it discussed factors which can influence or attract the university students to come to Xiang Fu Hai. The questionnaire uses the Indonesian language to prevent misunderstanding by the respondents.

The respondents were university students from Ciputra University and Petra University Students. The reason why I chose them because these two universities are the most potential markets of Xiang Fu Hai. It can be seen form the tuition fee of those universities. The tuition fee is quite high and only suitable for middle-upper class people. In Petra Christian University, the tuition fees start from IDR 7.500.000,00 until IDR 30.000.000,00. For entering the Department of Civil Engineering at Petra Christian University for batch 2019, the applicants or students have to pay IDR 22.000.000,00. In Ciputra University, the tuition fees start from IDR 29.000.000,00 until IDR 340.000.000,00. For entering International Business Management at Ciputra University for batch 2019, the applicants have to pay IDR 35.000.000,00. Ciputra University is also located in the West Surabaya, $10 \mathrm{~km}$ away from Vasa Hotel Surabaya. To go to Ciputra University, most people use or pass HR Muhammad street to reach Citraland area. 
That is why students from those universities are possible to be Xiang Fu Hai's new target market.

From Petra Christian University (PCU), I chose some departments from 7 faculties as the representative of PCU's students. There are English for Business Communication, English for Creative Industry, Mechanical Engineering Department, Informatics Engineering Department, Department of Civil Engineering, The Architecture Department, Hospitality Management Program, The Tax Accounting Department, Business Accounting Department, Business Management Program, Finance Program, Tourism Department, Teacher Education Study Program, Communication Science Department, Interior Design Studies Program, and Visual Communication Design. From Ciputra University, I choose 6 departments to be the representative of Ciputra University students. There are International Business Management (Regular and International class), Marketing Communication, Visual Communication Design, Psychology, Hotel and Tourism Business, and Culinary Business.

I also chose my respondents based on the gender which is female and male. 2 out of 3 or $68 \%$ of the respondents are female. I chose more female because of their consumer behavior. Based on "Consumer behavior and marketing strategy" book (2008), women's value of belongings tends towards caring, sharing, and cooperating. It is different from men's value which is controlling, selfishness, and dominating. Marketers think this finding would be beneficial to develop marketing strategies. In the late 1990s, they started to see women as a special group and most potential customers. Women can affect more than 80 percent of all purchases. Besides, $25 \%$ of working women have high-paying management than their spouses. It made Tom Peters, a famous business author, state "Women are opportunity no. 1." In "Consumer behavior: buying, having, and being" by Solomon (2013), some analysists say that we start entering "sheconomy" that woman is going to dominate the markets. According to Diaz-Méndez and van den Broek (2017) in "Eating out in modern societies" article, in the past twenty years, there is a change in eating out. The number of women who visit restaurants is always increase. The reasons of eating out are not only to save time and money or save energy, but rather to eat with others (sociable experience). It has also been proved by the most Xiang Fu Hai's customers that are women.

\section{FINDINGS AND DISCUSSION}

From the result of the questionnaire that has been conducted, there were some factors found. These factors can help Xiang Fu Hai to attract university students as a new target market to come on weekdays. After scoring it, the most factor that attracted customers was the atmosphere that was 13,3 percent of respondents chose it. The second was the price of the menu that was 12,4 percent. The third was a menu or variety of the food that was 12,2 percent. The respondents chose the atmosphere as one of the most attractive factors too. The Chinese restaurant was identic with family which had a warm atmosphere. This atmosphere of the restaurant that could make them comfort became one of attractive factor.

Then, the price was placed in the second factor which made customers come to a restaurant. Most of the respondents chose to eat with a suitable budget for them. I asked how much money the respondents were willing to spend to eat out. There were three kinds of set menu's prices which I asked in the questionnaire. First is the price of the common set menu, such as ala carte and big or family set menu. From the result, more than half of the respondents, 27 respondents or 54 percent, were willing to spend IDR 100.000,00 - IDR 249.999,00 for eating out in the five-star hotel. Next is the price of individual set menu. 30 respondents or 60 percent chose IDR $100.000,00$ - IDR $149.999,00$ to be their budget for buying an individual set menu. Last is the price of all you can eat set menu. Almost half of the respondents, 24 respondents or 48 percent, were willing to spend IDR 150.000,00 - IDR 199.999,00. 
Table 1.1. The price that the respondents were willing to pay for eating out in the five-star hotel

\begin{tabular}{|c|c|c|c|c|}
\hline \multirow[b]{2}{*}{ Set Menu } & \multicolumn{4}{|c|}{ Choice Analysis } \\
\hline & Price Range & $\begin{array}{l}\text { Number of } \\
\text { Respondents }\end{array}$ & Percentage & Rank \\
\hline \multirow{5}{*}{$\begin{array}{l}\text { Ala Carte / } \\
\text { Big/family }\end{array}$} & 100.000 - 249.999 & 27 & $54 \%$ & 1 \\
\hline & $250.000-499.999$ & 20 & $40 \%$ & 2 \\
\hline & $500.000-749.999$ & 2 & $4 \%$ & 3 \\
\hline & 750.000 - 999.999 & 0 & $0 \%$ & 5 \\
\hline & $\geq 1.000 .000$ & 1 & $2 \%$ & 4 \\
\hline \multirow[b]{2}{*}{ Set Menu } & \multicolumn{4}{|c|}{ Choice Analysis } \\
\hline & Price Range & $\begin{array}{l}\text { Number of } \\
\text { Respondents }\end{array}$ & Percentage & Rank \\
\hline \multirow{4}{*}{ Individual } & $100.000-149.999$ & 30 & $60 \%$ & 1 \\
\hline & $150.000-199.999$ & 15 & $30 \%$ & 2 \\
\hline & 200.000 - 249.999 & 5 & $10 \%$ & 3 \\
\hline & $\geq 250.000$ & 0 & $0 \%$ & 4 \\
\hline \multirow[b]{2}{*}{ Set Menu } & \multicolumn{4}{|c|}{ Choice Analysis } \\
\hline & Price Range & $\begin{array}{l}\text { Number of } \\
\text { Respondents }\end{array}$ & Percentage & Rank \\
\hline \multirow{4}{*}{$\begin{array}{l}\text { All you can eat } \\
\text { Dim Sum }\end{array}$} & $100.000-149.999$ & 17 & $34 \%$ & 2 \\
\hline & $150.000-199.999$ & 24 & $48 \%$ & 1 \\
\hline & 200.000 - 249.999 & 9 & $18 \%$ & 3 \\
\hline & $\geq 250.000$ & 0 & $0 \%$ & 4 \\
\hline
\end{tabular}

Last, the menu was placed in the third factor which made customers come to a restaurant. Interviewing some respondents, I asked why the menu and variety was the factor that they chose. They said when people went to Chinese restaurants the first thing that they seek was the food. Variety of menu or food which was different from other restaurants made them interested to come. Third question asked what kinds of the set menu the university students prefer. Based on the result of the questionnaire, 22 respondents or 44 percent chose all you can eat set menu, 12 respondents or 24 percent chose the individual set menu, 9 respondents or 18 percent chose big or family set menu, and 7 respondents or 14 percent chose ala carte menu. Most of the respondents prefer all you can eat because they could eat as much as they abled with a price which already set. They did not have to worry with over budget. Next, the respondents who chose individual set menu said that this kind of menu can be enjoyed without being hurried. For, there was no time limit. It also made them easier to split the bills if they went with friends.

Table 1.2. Set menus that were interested in the respondents

\begin{tabular}{|l|c|c|c|}
\hline \multirow{2}{*}{ Set Menu } & \multicolumn{3}{|c|}{ Choice Analysis } \\
\cline { 2 - 4 } & $\begin{array}{c}\text { Number of } \\
\text { Respondents }\end{array}$ & Percentage & Rank \\
\hline Individual & 12 & $24 \%$ & 2 \\
\hline
\end{tabular}




\begin{tabular}{|l|c|c|c|} 
Big/family & 9 & $18 \%$ & 3 \\
\hline Ala Carte & 7 & $14 \%$ & 4 \\
\hline All you can eat & 22 & $44 \%$ & 1 \\
\hline
\end{tabular}

The other question asked whether a five-star hotel could be an interesting factor that made university students come to Xiang Fu Hai. In this question, it was set that there were two Chinese restaurants which could give the same quality and price. However, the first restaurant was located in the common location and the second restaurant was located in a five-star hotel, which one of the restaurants the respondents chose. Based on the result of the questionnaire, 28 respondents preferred to eat in a five-star hotel Chinese restaurant, and other respondents chose to eat out in a common Chinese restaurant. I interviewed the respondents why they chose to eat in a five-star hotel, and they answered that eating out in five-star hotel could give personal prestige for the customers. One of the respondents also said that the Chinese restaurant in the five-star hotel had its own uniqueness than common Chinese restaurants. It could be a new experience to eat out Chinese food in a five-star hotel. The respondents who chose common Chinese restaurants said that they were afraid of eating out in five-star hotel because of the price. The five-star hotel was identical with prestige and expensive. Those characteristics have become a mindset in society, although the price of the food actually fitted their budget. When I asked, if the price fitted with the money that they were willing to spend, whether they wanted to eat in a five-star hotel, they answered yes.

Table 1.3. A five-star hotel could be an interesting factor that made university students come to Xiang Fu Hai

\begin{tabular}{|l|c|c|c|}
\hline \multirow{2}{*}{$\begin{array}{l}\text { Location of the Chinese } \\
\text { Restaurant }\end{array}$} & \multicolumn{3}{|c|}{ Choice Analysis } \\
\cline { 2 - 4 } & $\begin{array}{c}\text { Number of } \\
\text { Respondents }\end{array}$ & Percentage & Rank \\
\hline Common place & 22 & $44 \%$ & 2 \\
\hline Five-star hotel & 28 & $56 \%$ & 1 \\
\hline
\end{tabular}

If male and female were compared, male respondents had a tendency to choose to eat in common Chinese restaurant. 9 out of 16 male respondents chose to eat in common restaurant than in a five-star hotel restaurant. However, based on female respondents' data, 21 out of 34 chose to eat ours in a five-star hotel. It can be concluded that women had higher potency to be Xiang Fu Hai's new customers

Table 1.4. Gender that has higher potency to be Xiang Fu Hai's new customer

\begin{tabular}{|l|c|c|}
\hline \multirow{2}{*}{ Male Respondents } & \multicolumn{2}{|c|}{ Choice Analysis } \\
\cline { 2 - 3 } & Number of Respondents & Percentage \\
\hline Common place & 9 & $56 \%$ \\
\hline Five-star hotel & 7 & $44 \%$ \\
\hline \multirow{2}{*}{ Female Respondents } & Number of Respondents & Percentage \\
\cline { 2 - 3 } & 21 & $62 \%$ \\
\hline Common place & 13 & $38 \%$ \\
\hline Five-star hotel & \multicolumn{2}{|c|}{ Choice Analysis } \\
\hline
\end{tabular}


Table 4.3.13. University which has a higher demand on all you can eat Dim Sum set menu

\begin{tabular}{|l|c|c|}
\hline \multirow{2}{*}{ Ciputra University } & \multicolumn{2}{|c|}{ Choice Analysis } \\
\cline { 2 - 3 } & Number of Respondents & Percentage \\
\hline Individual & 8 & $32 \%$ \\
\hline Big/family & 5 & $20 \%$ \\
\hline Ala Carte & 3 & $12 \%$ \\
\hline All you can eat & 9 & $36 \%$ \\
\hline \multicolumn{2}{|c|}{ Choice Analysis } \\
\hline Petra Christian & \multicolumn{2}{|c|}{} \\
\cline { 2 - 3 } University & Number of Respondents & Percentage \\
\hline Individual & 4 & $16 \%$ \\
\hline Big/family & 4 & $16 \%$ \\
\hline Ala Carte & 4 & $52 \%$ \\
\hline All you can eat & 13 & \\
\hline
\end{tabular}

Last, I asked which university has a higher demand on all you can eat Dim Sum set menu. According to the result, it could be seen Petra Christian University students that had higher demand on this kind of set menu. 13 out of 25 Petra Christian University students chose all you can eat Dim Sum set menu than other set menus. However, in Ciputra University's result, only 9 of 25 respondents who chose all you can eat Dim Sum set menu.

These findings of the questionnaire are the most important factor that can help Xiang Fu Hai to increase the number of customers on weekdays and understand more factor that attract university students as a new target market. By implementing these factors and designing the offers which are suitable for the target market, I believe the university students can be interested and come to Xiang Fu Hai of Vasa Hotel Surabaya on weekdays.

\section{CONCLUSION}

In conclusion, I decided to conduct marketing research to identify the factors that attaract Ciputra and Petra Christian University students as a new target market to come to Xiang Fu Hai of Vasa Hotel Surabaya on weekdays, for my Business Communication Final Project (BCFP) report. The problem of Xiang Fu Hai is the low number of customers on weekdays. Xiang Fu Hai has already established in 2017, but Xiang Fu Hai performance is still low on weekdays. On weekends, Xiang Fu Hai is always full by customers that most of them are families. The existing customers will not move to eat out on weekdays, because they only can be complete on weekends. Therefore, Xiang Fu Hai has to find a new target market that is potential to be its customers. After doing research, university students are the most potential target market for Xiang Fu Hai. To find the factors which make them attract with the Xiang Fu Hai offers, Xiang Fu Hai has to conduct a research about it.

By conducting a research based on what the university students' needs and demands, it will be a good start for Xiang Fu Hai to make an effective offer. Xiang Fu Hai can have strategies to attract university students who are their new target market to come to Xiang Fu Hai and understand the cause of the problem. The questions of the questionnaire also depend on the Xiang Fu Hai condition or resources and based on the problem that wanted to be solved. This research will be useful for a long-term plan. After having the respondents' answer or data, I 
observed the data to find the factors and made a report of it. All the results are compiled and summarized on a research report. Based on the research, I will also give an example in the form of a digital flyer, to know how the research can be used.

I do hope Xiang Fu Hai can use the marketing research and the example of the promotional tool for the next offer to solve the problem of low number custmers on weekdays. They can use it to improve the promo that Xiang Fu Hai already had. Xiang Fu Hai also can conduct more research in order to know the needs and the demands of their customers. For, the demand of the market can change rapidly following the technology. Therefore, the company has always to keep up with the times and make an innovative offer to make the customers always come back to Xiang Fu Hai.

\section{REFERENCES}

Alexander, Hilda. B. (2018). Milenial, generasa "seksi" yang makin diperebutkan. Retrieved from: https://properti.kompas.com/read/2018/09/22/211646821/milenial-generasiseksi-yang-makin-diperebutkan?page=all

Debora, Yantina. (2017). Ke mana mengalirnya uang para milenial?. Retrieved from: https://tirto.id/ke-mana-mengalirnya-uang-para-milenial-cv76

Diaz-Méndez and van den Broek. (2017). Eating out in modern societies: An overview of a heterogeneous habit. In Appetite. 1-4. Retrieved from http://dx.doi.org/10.1016/j.appet.2017.05.003

Peter, J. Paul and Olson, Jerry C. (2008). Consumer behavior and marketing strategy. New York, NY: McGraw-Hill Companies.

Solomon, Michael R. (2013). Consumer behavior: buying, having, and being.England: Pearson Education Limited. 